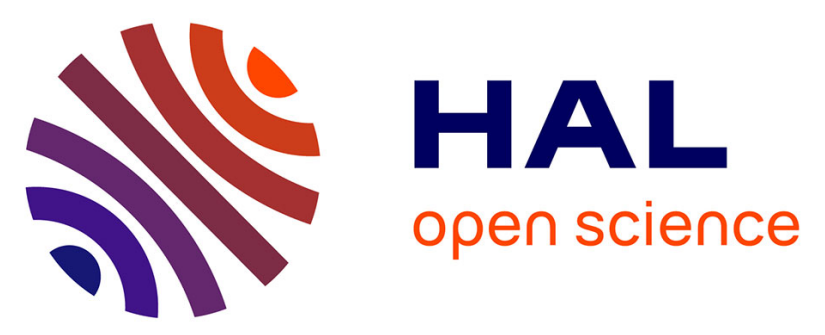

\title{
Transient simulations over the Common Era in PMIP4/CMIP6
}

\author{
Johann Jungclaus, Eduardo Alastrue de Asenjo, Alexandre Cauquoin, \\ Shih-Wei Fang, Myriam Khodri, Stephan Lorenz, Rumi Ohgaito, Teffy Sam, \\ Claudia Timmreck, Matthew Toohey, et al.
}

\section{To cite this version:}

Johann Jungclaus, Eduardo Alastrue de Asenjo, Alexandre Cauquoin, Shih-Wei Fang, Myriam Khodri, et al.. Transient simulations over the Common Era in PMIP4/CMIP6. EGU General Assembly 2021, Apr 2021, online, France. 10.5194/egusphere-egu21-12106 . hal-03213371

\section{HAL Id: hal-03213371 \\ https://hal.sorbonne-universite.fr/hal-03213371}

Submitted on 30 Apr 2021

HAL is a multi-disciplinary open access archive for the deposit and dissemination of scientific research documents, whether they are published or not. The documents may come from teaching and research institutions in France or abroad, or from public or private research centers.
L'archive ouverte pluridisciplinaire HAL, est destinée au dépôt et à la diffusion de documents scientifiques de niveau recherche, publiés ou non, émanant des établissements d'enseignement et de recherche français ou étrangers, des laboratoires publics ou privés. 
EGU21-12106

https://doi.org/10.5194/egusphere-egu21-12106

EGU General Assembly 2021

(c) Author(s) 2021. This work is distributed under

the Creative Commons Attribution 4.0 License.

\section{Transient simulations over the Common Era in PMIP4/CMIP6}

Johann Jungclaus ${ }^{1}$, Eduardo Alastrue de Asenjo ${ }^{1}$, Alexandre Cauquoin ${ }^{2,3}$, Shih-Wei Fang ${ }^{1}$, Myriam Khodri ${ }^{4}$, Stephan Lorenz ${ }^{1}$, Rumi Ohgaito ${ }^{5}$, Teffy Sam ${ }^{1}$, Claudia Timmreck ${ }^{1}$, Matthew Toohey ${ }^{6}$, Martin Werner ${ }^{2}$, Kohei Yoshida ${ }^{7}$, Davide Zanchettin ${ }^{8}$, and Qiong Zhang ${ }^{9}$

${ }^{1}$ Max-Planck-Institute for Meteorology, Hamburg, Germany

${ }^{2}$ Alfred Wegener Institute, Helmholtz Centre for Polar and Marine Research, Bremerhaven, Germany

${ }^{3}$ Institute of Industrial Science, The University of Tokyo, Chiba, Japan.

${ }^{4}$ LOCEAN, IRD/IPSL, Sorbonne University, Paris, France

5 Japan Agency for Marine-Earth Science and Technology, Yokohama, Japan

${ }^{6}$ University of Saskatchewan, Institute of Space and Atmospheric Studies Physics and Engineering Physics, Saskatchewan,

Canada

${ }^{7}$ Meteorological Research Institute, Japan Meteorological Agency, Tsukuba, Japan

${ }^{8} \mathrm{Ca}$ Foscari University of Venice Dept. of Environmental Sc., Informatics and Statistics, Venice, Italy

${ }^{9}$ University of Stockholm, Dept. of Physical Geography, Stockholm, Sweden

The Common Era ( $\mathrm{CE}$, i.e. the two millennia before the industrialization) is among the periods selected by the Paleo Model Intercomparison Project (PMIP) for transient experiments contributing to PMIP4. For PMIP4, novel estimates and updates of external forcing have been compiled (Jungclaus et al., GMD, 2017). In addition to the Tier-1 category simulation "past 1000 " for the period $850 \mathrm{CE}$ to $1849 \mathrm{CE}$, the Tier-3 "past2k" experiment covers the entire CE. After serious delays, the ESGF is now being filled by modeling groups running the transient simulations.

Here we provide an overview of the simulations, discuss the range of applied models, and present first results of common analyses from past 1000 and subsequent historical simulations. We discuss the long-term climate evolution, the range of internally-generated and externally-forced variability and specific aspects of the response to volcanic forcing.

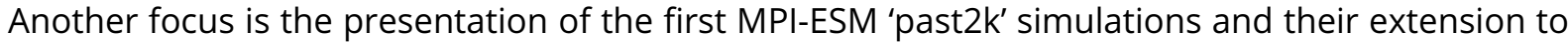
include water isotopes in MPI-ESM-WISO. These simulations extend the pool of current ESM simulations into the 1st millennium CE and represent an important basis to assess the models' response to external forcing and improved model-data comparison. We analyze regional trends and variations over the last 2000 years in comparison with PAGES2k reconstructions. 